\title{
IMPLEMENTASI TOTAL QUALITY MANAGEMENT TERHADAP KUALITAS PRODUK PADA PT. TRI MUSTIKA COCOMINAESA AMURANG
}

\author{
Meylani Selvi Kading ${ }^{1}$, Sifrid S. Pangemanan ${ }^{2}$, Natalia Y.T. Gerungai ${ }^{3}$ \\ 1,2,3 Jurusan Akuntansi, Fakultas Ekonomi dan Bisnis, Universitas Sam Ratulangi, Jl. Kampus Bahu, Manado, \\ 95115, Indonesia \\ E-mail: meylanikading03@gmail.com
}

\begin{abstract}
The influence of globalization in the industrial world today has caused competition between companies to become increasingly strict and competitive. The company's success is seen from the quality of products produced by the company. Total Quality Management is an ongoing process to achieve a better level of quality in meeting customer needs. The purpose of this research is to find out how the implementation of Total Quality Management at PT. Tri Mustika Cocominaesa Amurang. The method used is descriptive analysis. PT. Tri Mustika Cocominaesa applies ethics, integrity, trust, training, teamwork, leadership, appreciation, and communication to be successful in implementing Total Quality Management.
\end{abstract}

Keywords: Total Quality Management $\{T Q M\}$, Product Quality.

\section{PENDAHULUAN}

Dalam dunia bisnis yang semakin ketat persaingannya, maka perusahan dituntut untuk dapat terus berkembang melakukan strategi kompetisi dalam melayani konsumen seperti menciptakan produk yang berbeda dan berkualitas. Kualitas Produk merupakan pergerak kepuasan yang utama bagi pelanggan serta kualitas produk ini merupakan sudut pandang yang umum. Untuk menghasilkan kualitas produk yang prima maka perusahan dituntut untuk terus memperbaiki produktivitas agar kualitas yang dihasilkan lebih baik. Produktivitas dan kualitas adalah semboyan dalam persaingan bisnis saat ini, perusahaan tidak hanya mengukur produktivitas dan perbaikan yang mendesak namun juga berkeras Pada kualitas berarti membawa ke pasar produk yang memuaskan pelanggan, meningkatkan penjualan, dan meningkatkan keuntungan (Lesti Hertati 2016). Sebagaimana diketahui total quality management merupakan proses berkelanjutan untuk mencapai tingkat kualitas lebih baik. Maka dengan diberlakukan total quality management di perusahaan diharapkan kualitas produk yang dihasilkan akan lebih baik hingga dapat memenuhi kebutuhan pelanggan.

\section{TINJAUAN PUSTAKA}

Pengertian Akuntansi. Menurut Homenta (2015), akuntansi adalah proses dari data yang belum diolah menjadi informasi yang siap digunakan, informasi yang dimaksudnya diperoleh dari berbagai kegiatan seperti mengumpulkan, mengidentifikasi, mencatatan serta mengikhtisaran data keuangan. Dan kemudian data keuangan yang diringkas menghasilkan informasi keuangan yang selanjutnya diteruskan kepada para pengguna dan kemudian akan ditafsirkan untuk kepentingan guna pengambilan keputusan ekonomi.

Akuntansi Manajemen. Menurut Henry Simamora (2012:13) Akuntansi Manajemen merupakan proses mengidentifikasi, mengukuran menghimpunan, analisa, menyusunan, menafsiran dan mengumpulkan informasi mengenai keuangan yang dipergunakan oleh manajemen untuk perencanaan, pengevaluasi serta mengendalikan kegitan usaha yang ada dalam organisasi, serta untuk menentukan kegunaan dan konsep-konsep sumber daya yang tepat.

Total Quality Management (TQM). Mashagba (2014) Total Quality Management yang sangat penting dalam konteks aplikasi ilmiah di berbagai institusi. Namun, pilar-pilar 
inilah yang akan menunjukkan fakta dasar yang harus didasarkan pada kebutuhan saat memulai menggunakan metode ini aplikasi praktis di berbagai organisasi karena mengacu pada konstruksi gagasan filosofis yang mendasari aspek ilmiah aplikasi yang telah beragam pendapat para akademisi dan pemikir, berikut ini merupakan 8 element kunci dalam organisasi dalam menerapkan TQM :

1. Etika. Etika yaitu disiplin yang sangat berkaitan dengan baik dan buruk sifat yang ada pada bermacam kondisi. Etika merupakan dua sisi yang saling berhubungan serta dilambangkan oleh bisnis dalam menjelaskan serta memberi petunjuk bagi semua anggota serta etika harus melekat dalam diri masing-masing, dan dalam setiap pekerjaan. Sedangkan etika individu mencakup kesalahan atau kebenaran pada setiap orang.

2. Kejujuran (integritas). Integritas yang dimaksudkan mencakup nilai-nilai, keadilan, moral dan kesetiaan serta kejujuran terhadap keikhlasan dan kebenaran dari setiap individu. sifatnya berupa apa yang menjadi harapan atau keiinginan pelanggan dan apa layak/pantas untuk diterima oleh pelanggan.

3. Kepercayaan. Kepercayaan yaitu hasil dari kejujuran serta bersifat disiplin. Tanpa kepercayaan, struktur dari TQM tidak akan berlajan dengan baik. Karena dengan memberikan kepercayaan akan sangat membantu dalam perkembangan serta dapat partisipasi penuh dari anggota-anggota organisasi.

4. Pelatihan (training). Training merupakan hal yang sangat-sangat penting bagi setiap karyawan yang ada dalam organisasi. Karena dengan training akan membuat karyawan menjadi lebih proaktif dan produktif. Pimpinan bertanggungjawab dalam menerapkan TQM serta, memiliki tanggungjawab dalam mengajarkan konsep-konsep dasar dari TQM kepada semua karyawan yang ada.

5. Kerja tim (team work). Kerjasama tim merupakan salah satu sebuah elemen kunci dari TQM, yang membantu organisasi untuk dapat mencapai kesuksesan. Karena dengan membentuk tim kerja, pasti akan mempermuda organisasi untuk memperoleh cara yang tepat dan cepat terhadap penyelesaian masalah yang terjadi.

6. Kepemimpinan (leadership). Kepemimpinan adalah sesuatu yang sangat penting dalam menerapkan TQM. Karena kepemimpinan selalu ada pada semua tempat di suatu organisasi. Kepemimpinan. Dalam menerapkan TQM tentunya membutuhkan pimpinanpimpinan yang mampu mengarahkan pandangan atau visi serta memberikan contoh, dan membuat arahan-arahan baik yang mudah dipahami oleh bawahannya serta menanamkan nilai-nilai yang baik sebagai panduan dalam bekerja. TQM akan berhasil diaplikasikan di suatu organisasi jika pimpinan secara intens dapat membimbing bawahannya.

7. Penghargaan (recognition). Penghargaan merupakan elemen yang terakhir dari sistem TQM. Sangat baik jika diberikan kepada karyawan yang memiliki loyalitas yang tinggi dan untuk saran-saran capaian-capaian yang memuaskan. Baik yang dihasilkan oleh individu atau kelompok. Penghargaan kepada pribadi atau kelompok yang memiliki loyalitas akan membuat individu atau kelompok yang lain memiliki rasa terdorong untuk bisa berusaha lebih baik lagi sehingga boleh mendapat penghargaan yang sama untuk diri sendiri ataupun untuk kelompok.

8. Komunikasi. Komunikasi akan mengikat merupakan kunci dari keberhasilan TQM. Para pemimpin harus mengupayakan transparansi mengenai komunikasi dimana semua karyawannya berhak menerima dan mengirim informasi tentang langkah-langkah TQM. merupakan salah satu hal yang sangat penting ketika komunikasi disampaikan dengan baik. 
Kualitas Produk. Kualitas produk yaitu tingkat kemampuan dari produk tersebut dalam menyatakan kegunaanya, hal ini termasuk semua kemampuan, ketepatan, kemudahan dalam pengoperasian dan perbaikan produk juga kelengkapan produk-produk lain Kotler dan Amstrong, 2012:283 dalam V. Broto (2016). Kualitas suatu istilah sangat tergantung pada situasi. Dilihat dari sudut pandangnya konsumen, secara subjektif kualitas adalah sesuatu yang cocok sengan selera. Dimensi Kualitas Produk:

1. Kinerja, yaitu yang berhubungan dengan sifat khas produk tersebut.

2. Daya Tahan, yang berarti seberapa lama ketahanan umur produk yang bersangkutan sebelum produk terganti. Karena semakin tinggi tingkat penggunaan konsumen terhadap produk tersebut maka semakin meningkat besar pula daya tahan produk.

3. Kesesuaian dengan spesifikasi, yaitu bagaimana jauh kemampuan operasi dasar dari sebuah produk dalam memenuhi proses tertentu dari konsumen dan tidak menemukan produk yang cacat.

4. Keandalan, yaitu prioritas bahwa produk akan bekerja sesuai dengan fungsi. Apakah memuaskan ataupun sebaliknya dalam jangka waktu tertentu.

5. Estetika, merupakan hubungan dengan penampilan dari produk tersebut. Biasa terlihat dari bentuk, tampak, rasa, dan bau produk.

6. Kesan Kualitas, yaitu hasil dari digunakannya ukuran tertentu yang diberlakukan dengan cara tidak langsung karena mungkin terdapat konsumen yang kurang mengerti karena tidaknya menerima informasi mengenai produk tersebut.

\section{Penelitian Terdahulu}

1. Hidayati (2015) melakukan penelitian berjudul Pengaruh Total Quality Management Terhadap Kualitas Produk Pada CV. DUA SINGA Banyuwangi. Hasil menunjukkan bahwa TQM berpengaruh signifikan terhadap kualitas produk.

2. Galih Fajar Muttaqin (2015) melakukan penelitian berjudul Pengaruh Implementasi Total Quality Management Terhadap Kinerja Keuangan Sebagai Variabel intervening. Hasil menujukkan Total Quality Management memiliki pengaruh yang positif dan signifikan terhadap kinerja keuangan.

3. Hidayati (2015) melakukan penelitian berjudul Pengaruh Total Quality Management Terhadap Kualitas Produk pada CV. Dua Singa Banyuwangi. Hasil menunjukkan focus terhadap pelanggan berpengaruh signifikan, pendidikan dan pelatihan berpengaruh signifikan dan TQM berpengaruh secara simultan terhadap kualitas produk.

4. Lesti Hartati (2016) melakukan penelitian berjudul just in time, value chain, total quality management, part of technical strategic management accounting. Hasil menunjukkan just in time, value chain, total quality management memililiki peranan penting dalam pengelolaan akuntansi strategis.

5. Maria Soraya Purba (2014). Melakukan penelitian berjudul Pengaruh total quality management terhadap Kinerja perusahaan dengan kepemimpinan dan Budaya kualitas sebagai variabel intervening. Hasil menunjukkan total quality management berpengaruh terhadap kinerja, mempengaruhi kepemimpinan di perusahaan dan mempengaruhi budaya kualitas.

6. Oey Hannes Widjaya (2014). Melakukan penelitian berjudul Pengaruh Total Quality Management (TQM) dan Quality Management Information (QMI) Terhadap Kinerja Perusahaan. Hasil penelitian menunjukkan Terdapat pengaruh positif TQM terhadap kinerja PT Bridgestone Tire Indonesia Terdapat pengaruh positif QMI terhadap kinerja PT Bridgestone Tire Indonesia Paling sedikit ada satu variabel bebas (TQM atau QMI) yang mempengaruhi variabel tidak bebas (kinerja) pada PT Bridgestone Tire Indonesia.

7. Janrilius Doli Butarbutar (2017). Analisis penerapan sistem akuntansi manajemen terhadap pengendalian kualitas produk. Hasil penelitian menunjukkan sistem akuntansi manajemen terhadap pengendalian kualitas sudah diberlakukan. 
8. Ade Dya Haryani (2015). Melakukan pnelitian berjudul Pengaruh Total Quality Management (Tqm)Terhadap Biaya Kualitas Dan Kualitas Produk Serta Implikasinya Terhadap Kinerja Perusahaan Dengan Budaya Kualitas Sebagai Variabel Moderasi. Hasil penelitian menunjukkan bahwa Total Quality Management (TQM) berpengaruh terhadap biaya kualitas dan kualitas produk.

\section{METODE PENELITIAN}

Jenis Penelitian. Dalam penelitian ini peneliti menggunakan jenis penelitian deskriptif dengan pendekatan kualitatif yaitu meneliti dengan cara peneliti mengunjungi langsung tempat penelitian danpeneliti melakukan interaksi dengan tempat penelitian. kualitatif yaitu berbentuk uraian berupa penjelasan secara tertulis yang peneliti temukan dari sumber-sumber yang terkait. Dalam penelitian kualitatif Sugiono (2016:1) adalah cara yang ambil peneliti dalam melakukan penelitian untuk melihat/memantau langsung situasi kondisi tempat penelitian secara nyata, yang dimana peneliti merupakan alat yang digunakan dalam mengumpulkan data informasi. Lokasi penelitian di lakukan di Amurang tepatnya pada salah satu perusahan tepung kelapa yaitu PT Trimustika Cocominaesa (TMC) Amurang, dengan alamat Jalan Raya A.K.D km 90 Teep Amurang, Minahasa Selatan. Waktu penelitian ini dilakukan pada bulan maret 2018.

\section{Prosedur Penelitian}

1. Mencari dan meenyimpulkan masalah, serta menetapkan tempat penelitian yang sesuai dengan masalah.

2. Merancangkan penelitian dengan cara peneliti membuat surat di akademik berupa surat permohonan yang ditujukan kepada pimpinan PT. Tri Mustika Cocominaesa Amurang.

3. Setelah surat permohonan diterima, selanjutnya peneliti mengumpulkan data-data yang berguna dengan cara peneliti melakukan wawancara dengan pimpinan, peneliti melakukan observasi di tempat penelitian serta peneliti mlakukan dokumentasi sebagai pelengkap data penelitian.

4. Selanjutnya data yang terkumpul, peneliti sajikan serta menarik kesimpulan serta memberikan saran-saran guna melengkapi penelitian.

\section{Sumber Data}

1. Data primer. Peneliti datang secara langsung ke tempat penelitian, agar peneliti mendapat data primer peneliti melakukannya dengan cara mewawancarai pimpinan PT Tri Mustika Cocomiaesa (TMC) Amurang.

2. Data Sekunder. Data yang diperoleh peneliti secara tidak langsung yaitu dengan melihat media-media perantara berupa melihat penelitian yang telah dilakukan peneliti lain sebagai panduan peneliti dalam melakukan penlitian, cara lainnya yaitu dengan mencari buku-buku yang berkaitan dengan masalah yang diteliti serta mengakses website atau situs lainnya yang berkaitan.

\section{Teknik Pengumpulan Data}

1. Wawancara tak berstruktur (unstructured interview). Wawancara yang dimaksudkan yaitu penulis bebas bertanya tidak menggunakan pedoman terstruktur. Pedoman wawancara yang digunakan hanyalah pokok-pokok permasalahan. Narasumber dalam wawancara ini adalah Pimpinan dari PT. Tri Mustika Cocominaesa Amurang.

2. Teknik Dokumentasi. Peneliti melakukan dokumentasi untuk mendapatkan data yang mendukung penelitian ini.

Metode Analisis. Dalam penelitian ini, peneliti menggunakan metode berupa analisis kualitatif. Analisis kualitatif meliputi penilaian pendapat dan sikap dari seseorang, kelompok atau organisasi,. Data deskriptif dikumpulkan melalui cara membuat daftar pertanyaan dalam survei, wawancara, ataupun observasi (Indrawan dan Yaniawati, 2014: 56). 
Berdasarkan masalah dan teknik pengumpulan data penulis menggunakan teknik deskriptif kualitatif yaitu dengan cara menjabarkan kenyataan keadaan yang terjadi di objek tersebut dalam bentuk uraian kata-kata berdasarkan keterangan yang peneliti peroleh dari pihak-pihak terkait.

\section{HASIL PENELITIAN DAN PEMBAHASAN}

\subsection{Hasil Penelitian}

1. Etika. Berdasarkan hasil wawancara dengan ibu Sherly Dendeng selaku direktur di PT.Tri Mustika Cocominaesa, Perusahaan mengutamakan kedisiplinan karna sesuatu yang dilakukan dengan disiplin pasti akan menghasilkan kebaikan. disiplin yang diberlakukan di perusahaan yaitu disiplin waktu datang/pulang para karyawan dengan menggunakan fingerprint agar waktu datang/pulang terkontrol dengan baik, juga disiplin dalam bekerja, pada jam kerja karyawan harus bekerja, dan setiap karyawan memiliki tugas dan tanggungjawab masing-masing yang harus dikerjakan.

2. Integritas (kejujuran). Berdasarkan hasil wawancara dengan ibu Sherly Dendeng selaku direktur di PT.Tri Mustika Cocominaesa perusahaan selalu mengutamakan kejujuran dan sikap yang baik mulai dari pemimpin sampai kepada bawahan dengan menepakan prinsip-prinsip misi dan visi sebagai motovasi, bila terjadi kesalahan maka langsung memperbaiki supaya perusahaan dapat maju sesuai dengan visi dan misi yang dipegang perusahaan.

3. Kepercayaan. Berdasarkan hasil wawancara dengan ibu Sherly Dendeng selaku direktur di PT.Tri Mustika, Perusahaan menaruh kepercayaan yang besar kepada karyawan dengan memberi kebebasan terkendali bagi karyawan menyelesaikan tugas dan tanggungjawab yang ada pada masing-masing karyawan, serta mempercayai informasi yang diberikan karyawan sehubungan pekerjaan karena dengan informasi akan memudahkan proses pengambilan keputusan pelaksanaan.

4. Pelatihan. Berdasarkan hasil wawancara dengan ibu Sherly Dendeng selaku direktur di PT.Tri Mustika Cocominaesa, pelatihan di perusahaan belum diberlakukan.

5. Kerjasama Tim. Berdasarkan hasil wawancara dengan ibu Sherly Dendeng selaku direktur di PT.Tri Mustika Cocominaesa Kerjasama tim yang dibangun oleh PT.Tri Mustika Cocominaesa, bila terjadi kesalahan langsung memberikan solusi dan memperbaikinya, kerjasama tim tidak lepas dari komunikasi ,kejujuran dan etika yang baik. Walaupun tingkat ketidakhadiran karyawan yang tinggi namun perusahaan akan berusaha mencari solusi dalam masalah ini.

6. Kepemimpinan. Berdasarkan hasil wawancara dengan ibu Sherly Dendeng selaku direktur di PT.Tri Mustika Cocominaesa, Manajer selalu memberikan motivasi atau nasihat kepada keryawan dalam menjalankan tugas, agar dalam setiap tanggungjawab yang di kerjakan karyawan tidak menjadi terganggu dan selalu tepat waktu sesuai hasil yang diinginkan perusahaan, dan kiranya pemimpin selalu menjadi pendukung bagi perusahaan dala, mencapai hasil yang berkualitas sehingga dapat unggul dalam persaingan yang ada.

7. Penghargaan. Berdasarkan hasil wawancara dengan ibu Sherly Dendeng selaku direktur di PT.Tri Mustika Cocominaesa Penghargaan yang dilakukan perusahaan kepada tim atau individu yang penuh loyalitas berupa memberikan pujian dan memberikan bonus khusus.

8. Komunikasi. Berdasarkan hasil wawancara dengan ibu Sherly Dendeng selaku direktur di PT.Tri Mustika Cocominaesa, Manajer menjalin komunikasi yang baik dengan karyawan yang ada dengan selalu melakukan komunikasi kepada seluruh karyawan mengenai sesuatu yang akan dilakukan dalam usaha peningkatan mutu, memberikan informasi, memberikan arahan, dan mampu menjawab pertanyaan yang karyawan tanyakan, begitu juga antar karyawan menjalin komunikasi dengan baik. 


\subsection{Pembahasan}

1. Etika. Etika adalah suatu bentuk kedisiplinan yang sangat diharapkan oleh perusahaan dan perusahaan mengharapkan agar menghindarkan diri dari hal-hal yang kurang baik. disiplin yang diperhatikan yaitu disiplin waktu datang/pulang para karyawan, disiplin dalam bekerja, pada jam kerja karyawan harus bekerja, dan setiap karyawan memiliki tugas masing-masing yang harus dikerjakan.

2. Kejujuran. Perusahaan selalu mengutamakan kejujuran dan sikap yang baik mulai dari pemimpin sampai kepada bawahan dengan menepakan prinsip-prinsip misi dan visi sebagai motovasi, bila terjadi kesalahan maka langsung memperbaiki supaya perusahaan dapat maju sesuai dengan visi dan misi yang dipegang perusahaan.

3. Kepercayaan. Perusahaan menaruh kepercayaan yang besar kepada karyawan dengan memberi kebebasan terkendali bagi karyawan menyelesaikan tugas dan tanggungjawab yang ada pada masing-masing karyawan, serta mempercayai informasi yang diberikan karyawan sehubungan pekerjaan karena dengan informasi akan memudahkan proses pengambilan keputusan pelaksanaan.

4. Pelatihan. Dari hasil wawancara yang dilakukan peneliti Pelatihan yang ada perusahaan yaitu pelatihan inti seperti penggunaan mesin dan proses produksi.

5. Kerjasama Tim. Kerjasama tim yang dibangun oleh PT.Tri Mustika Cocominaesa yaitu bila terjadi kesalahan langsung memberikan solusi dan memperbaikinya, menghargai keputusan orang lain, kerjasama tim tidak lepas dari komunikasi ,kejujuran dan etika yang baik.

6. Kepemimpinan. Manajer selalu memberikan motivasi atau nasihat kepada keryawan dalam menjalankan tugas, agar dalam setiap tanggungjawab yang di kerjakan karyawan tidak menjadi terganggu dan selalu tepat waktu dalam menyelesaikan tugas serta selalu menjadi pendukung untuk mencapai perbaikan mutu.

7. Penghargaan. Penghargaan yang dilakukan perusahaan kepada karyawan yang penuh loyalitas berupa memberikan pujian dan memberikan bonus khusus. Tujuan perusahaan memberikan penghargaan agar menjadi motivasi bagi karyawan lain untuk dapat melakukan yang terbaik.

8. Komunikasi. Manajer menjalin komunikasi yang baik dengan karyawan yang ada dengan selalu melakukan komunikasi kepada seluruh karyawan mengenai sesuatu yang akan dilakukan dalam usaha peningkatan mutu begitu juga antara karyawan selalu menjalin komunikasi yang baik.

\section{KESIMPULAN DAN SARAN}

\subsection{Kesimpulan}

Hasil penelitian Total Quality Management yang terdiri dari etika, integritas, kepercayaan, pelatihan, kerjasama tim, kepemimpinan, penghargaan, dan komunikasi yang diberlakukan di PT. Tri Mustika Cocominaesa adalah:

1. Etika diberlakukan di PT. Tri Mustika Cocominaesa yaitu disiplin waktu datang/pulang para karyawan dengan menggunakan fingerprint agar waktu datang/pulang terkontrol.

2. Kejujuran, diterapkan mulai dari pemimpin sampai kepada bawahan dengan menepakan prinsip-prinsip misi dan visi sebagai motovasi.

3. Kepercayaan diberlakukan di PT. Tri Mustika Cocominaesa yaitu memberi kebebasan terkendali bagi karyawan menyelesaikan tugas dan tanggungjawab yang ada pada masing-masing karyawan, serta mempercayai informasi yang diberikan karyawan sehubungan pekerjaan.

4. Pelatihan yang dilakukan di PT. Tri Mustika Cocominaesa hayalah pelatihan inti berupa keterampilan cara memakai/menggunakan mesin. 
5. Kerjasama Tim yang dibangun di PT. Tri Mustika Cocominaesa tidak lepas dari komunikasi, kejujuran dan etika.

6. Kepemimpinan yang dilakukan di PT. Tri Mustika Cocominaesa yaitu pimpinan selalu memberi motivasi, arahan kepada karyawan dalam menjalankan tugas dan tanggungjawab.

7. Penghargaan yang ada di PT. Tri Mustika Cocominaesa hanya kepada tim atau individu yang penuh loyalitas berupa bemberian bonus khusus.

8. Komunikasi di PT. Tri Mustika Cocominaesa yaitu antara manajer dan karyawan selalu menjalin komunikasi yang baik begitu juga antara antar karyawan.

\subsection{Saran}

Berdasarkan hasil penelitian di PT. Tri Mustika Cocominaesa, maka saran yang dapat diberikan adalah diperlukan pelatihan yang lebih mendalam bagi setiap karyawan agar lebih produktif serta perusahaan juga perluh memperhatikan penyebab tingginya ketidakhadiran karyawan serta mencari alternatif yang mampu meningkatkan kinerja karyawan sehinggapun proses produksi tetap berjalan dengan baik.

\section{DAFTAR PUSTAKA}

Ade Dya Haryani 2015. Pengaruh Total Quality Management (Tqm)Terhadap Biaya Kualitas Dan Kualitas Produk Serta Implikasinya Terhadap Kinerja Perusahaan Dengan Budaya Kualitas Sebagai Variabel Moderasi. http://jp.feb.unsoed.ac.id/index.php/akuntable/article/view/530

Albertus Indratno, 2013.Prinsip-Prinsip Dasar Akuntansi. Penerbit Dunia Cerdas.

Erni Rismawati, 2016. Penerapam Total Quality Management $\{$ TQM\} Dalam Meningkatkan Laba PT. Joyfull Bakery Makasar. Jurnal Ekonomi Volume 4 No. 1 Juni 2016. http://ojs.unm.ac.id/economix/article/view/3843.

Galih Fajar Muttaqin, 2015. Pengaruh Implementasi Total Quality Management Terhadap Kinerja Keuangan Dengan Kualitas Kinerja Sebagai Variabel Intervening. https://www.e-jurnal.com/2017/01/pengaruh-implementasi-total-quality.html

Hidayati (2015) Pengaruh Total Quality Management Terhadap Kualitas Produk Pada CV. $D U A$ SINGA Banyuwangi. http://repository.unej.ac.id/bitstream/handle/123456789/64346/HIDAYATI.pdf?seque nce $=1$.

Indrawan, Poppy Yaniawati. 2014. Metodologi Penelitian. Penerbit Refika Aditama. Jakarta.

Lesti Hartati, 2016. Just In Time, Value Chain, Total Quality Management, Part of Technical Strategic Management Accounting. http://www.ijstr.org/final-print/apr2016/Just-InTime-Value-Chain-Total-Quality-Management-Part-Of-Technical-StrategicManagement-Accounting.pdf

Maria Soraya Purba, 2014. Pengaruh total quality management terhadap Kinerja perusahaan dengan kepemimpinan dan Budaya kualitas sebagai variabel intervening. https://anzdoc.com/pengaruh-total-quality-management-terhadap-kinerjaperusahaa151698144577555.html

Mashagba Salem Awwad Ibrahim, 2014. The Impact Of Total Quality Management (TQM) On The Efficiency Of Academic Performance - Empirical Study - The Higher Education Sector - The University Of Jordan'" international journal of scientific \& technology research volume 3, issue 4, april 2014.

Oey Hannes Widjaya (2014) Pengaruh Total Quality Management (TQM) dan Quality Management Information (QMI) Terhadap Kinerja Perusahaan. http://repository.untar.ac.id/352/1/2301-4974-1-SM.pdf

Reza Graha, 2013. Pengaruh implementasi total quality management terhadap Kinerja manajerial (studi pada pt. Pln area pelayanan dan jaringan kota malang). 
http://download.portalgaruda.org/article.php?article=189842\&val=6467\&title=PENG ARUH\%20IMPLEMENTASI\%20TOTAL\%20QUALITY\%20MANAGEMENT\%20 TERHADAP $\% 20 \% 20$ KINERJA $\% 20$ MANAJERIAL $\% 20 \% 20 \% 20$ (Studi $\% 20$ Pada $\% 2$ OPT.\%20PLN\%20Area\%20Pelayanan\%20dan\%20Jaringan\%20Kota\%20Malang). Sugiono, 2016. Memahami Penelitian Kualitatif. Penerbit Alfabeta. Bandung 